\title{
The Hidden Crisis: The Prato Industrial District and the Once Thriving Chinese Garment Industry
}

La crise cachée : le district industriel de Prato et le déclin de l'industrie de la confection chinoise

La crisis escondida: el distrito industrial de Prato et la antes floreciente industria china del vestuario

\section{Antonella Ceccagno}

\section{OpenEdition}

\section{Journals}

Electronic version

URL: https://journals.openedition.org/remi/6211

DOI: $10.4000 /$ remi.6211

ISSN: $1777-5418$

\section{Publisher}

Université de Poitiers

Printed version

Date of publication: 1 December 2012

Number of pages: 43-65

ISBN: 979-10-90426-06-1

ISSN: 0765-0752

\section{Electronic reference}

Antonella Ceccagno, "The Hidden Crisis: The Prato Industrial District and the Once Thriving Chinese Garment Industry", Revue européenne des migrations internationales [Online], vol. 28 - n4 | 2012, Online since 01 December 2015, connection on 14 April 2022. URL: http://journals.openedition.org/remi/ 6211 ; DOI: https://doi.org/10.4000/remi.6211 


\section{The Hidden Crisis: The Prato Industrial District and the Once Thriving Chinese Garment Industry}

\section{Antonella Ceccagno ${ }^{1}$}

\section{Introduction ${ }^{2}$}

Prato, a mid-sized city in Tuscany, Italy has become famous for two reasons. First, it is a well-known success story in the literature on industrial districts (IDs) and flexible specialization worldwide. Prato is where the main features of the typical Italian industrial districts reach their highest intensity, so much so that it has been described as an 'exemplary case' (Becattini, 2000). Second, Prato has become one of the areas in Europe with the highest Chinese population density. Starting from the early 1990s, growing numbers of Chinese migrants have settled in the industrial district first operating supplier firms and later also manufacturing firms in the apparel industry (Ceccagno, 2003b, 2007a and 2009).

This paper tackles the topic of migrants and the city, with a focus on the dynamics taking place in the most famous Italian ID (among the vast literature on Italian IDs, see Piore and Sabel, 1984; Becattini, 1990; Pyke et al., 1990; for a critique of the dominant mythology around Italian IDs see Hadjimichalis, 2006). Building on recent conceptualization on the different ways in which migrants and the cities shape and mold each other (Glick Schiller and Caglar, 2011), I intend to discuss the ways in which Chinese migrants and the city/ID of Prato together mutually constitute the local in the framework of the broader global and national dynamics. Prato is an ideal place to explore migrant agency at local level in the global processes that reposition previously thriving industrial districts and cities, now hard hit by global competition.

I analyze the dynamics that are taking place in Prato at a time when its garment industry, mainly run by Chinese migrants, is confronted with global changes and restrictive local policies and faces structural hindrances that threaten its very existence. In order to uncover the ongoing dynamics and

\footnotetext{
1 Associate Professor, University of Bologna, Dipartimento di Lingue, Letterature e Culture, via Cartolerie, 5, Bologna, Italy; antonella.ceccagno@unibo.it

2 I am grateful to an anonymous referee for valuable comments that improved the manuscript. The usual disclaimers apply.
} 
the reasons behind the crisis, I have conducted a three months' fieldwork in Prato (June-September 2012), interviewing Chinese migrants, Italian entrepreneurs and local policy makers, so that new fieldwork data can complement my previous long-term research on the Chinese in Prato.

This paper aims to document and explain the reasons for the crisis of the most successful fast fashion business run by Chinese in Europe, an industry that was thriving only a couple of years ago and was a rare example of first generation migrants being able to reach the position of manufacturers (Ceccagno, 2007a and 2009; on barriers to access to manufacturing to first generation migrants see $\mathrm{Yu}, 2002$ ).

Glick Schiller and Caglar (2008 and 2011) posit that some cities are upscaled and others are downscaled in the competitive processes of repositioning that are global in their reach. They suggest that studies of migrant pathways of incorporation in cities that find themselves disempowered and relatively impoverished within global restructuring can contribute to new and different analysis of the relationship between migrants and cities. Building on this conceptual approach, I show that Chinese migrants actively contribute to the competitive repositioning of the Prato ID, influencing the work market, the real estate market and the ID economy in general. I contend that Prato is an exemplary case that yields new insights into the interplay of scales - global, national, and local - in the complex dynamics between migrants and the locality. An assessment of the role of migrants in the process of repositioning of the Prato ID case appears far more controversial and therefore nuanced than in other localities where the rescaling of the locality is more straightforward and migrants' contribution to it is not bitterly contested by the main stakeholders.

\section{Chinese Migrants' Contribution to the Prato Industrial District}

Starting from the early 1990s, growing numbers of Chinese migrants have settled in the industrial district. By the end of 2011, 13,056 Chinese had the official residence in Prato (Comune di Prato, 2012). According to estimates, twice as much Chinese are living and working in Prato. Local government's officials sometimes venture to estimate that up to 50,000 Chinese migrants live in the city. However, both existing data and estimates on the number of Chinese migrants in Prato need to be handled with care. In fact, on the one hand, Chinese with residence permit in Prato are only part of the larger number of Chinese migrants living in the locality. In fact, in Italy a foreigner holding a so-called 'permit to stay' issued in one locality is free to live and work in cities different from the one where the document was issued. Given the high mobility of Chinese migrants in Europe and Italy (Ceccagno, 2003a; Pieke et al., 2004; Ceccagno and Rastrelli, 2008) the actual number of Chinese living in Prato may be significantly higher than the number of Chinese residents. Besides, undocumented Chinese migrants also live in the area. On the other hand, estimates of the number of Chinese working in Prato may be inflated for political reasons by those who want to show that there are too many Chinese in the district. 
The first Chinese-run contracting garment workshops in Prato opened in the early 1990s. Over the years, global and local conditions favored the development of a Chinese garment niche. The global market was being modified by the emergence of new exporting countries competing in the same sectors where Italy was one of the main exporters. At the same time, emigration from China was growing, and Italy was considered a place of opportunities for uneducated Chinese migrants who dreamed of becoming self-employers, able to become affluent very quickly. At the local level, before the arrival of the Chinese migrants, a modest garment industry outsourced most of its production to suppliers in Southern Italy (Colombi, 2001). Newly arrived Chinese migrants were received with a hearty welcome by local manufacturers since they were willing to establish their contracting activities in the very places where manufacturers clustered.

By operating in an informal economy and exploiting ethnic labor, Chinese workshops were able to charge competitive prices. In 2004 the direct cost of processing by Chinese workshops was equal to $5 \%$ of the final market price, or just one-half of the average processing cost charged by workshops run by Italians, according to a research conducted in the Carpi district, Emilia Romagna (Spinner, 2005). Besides, Chinese workshops guaranteed productive and organizational flexibility: faster processing and shorter lead-time before delivery (Ceccagno, 2003b and 2007a). Thus, thanks to the mushrooming of Chinese contracting workshops, little by little the previously modest local garment industry developed side-by-side with the larger ID's core textile industry.

In my previous research I have argued that Chinese businesses have been beneficial to the national garment industry (Ceccagno, 2003b and 2007a; see also Borsari et al., 2006). They have made possible for Made in Italy products to continue to be competitive. Resorting to Chinese contractors has represented the main response of Italian manufacturers to the major changes brought by the globalization of markets.

The mushrooming of Chinese businesses has been a lucrative business also for owners of old factory plants in the Macrolotto uno, an area gradually abandoned by natives when manufacturing activities had moved to the new industrial area. Dilapidated plants were rented to Chinese who used them as sleep-in workshops (Rastrelli, 2003). Over the years, Chinese growing demand for housing has increased the value of the city's real estate. In the decade from 1991 to 2001 the number of people working in the real estate market in Prato grew from 889 to 2,313, with an increase of 160\%; from 2001 to 2005 a further increase of $23 \%$ of real estate (together with business services) was registered in Prato (Dei Ottati, 2009b). With the crisis of the local textile industry - and within a national tax regime where taxes on real estate renting were about one third of taxes on profits -, more and more natives found it more advantageous to turn into real estate landlords renting industrial premises and flats to Chinese migrants.

A striking feature of Prato is that it is the only place in Italy where Chinese migrants have managed to become manufacturers themselves in large numbers. Starting from the mid-1990s, growing numbers of Chinese migrants previously active mainly as contractors have upscaled, becoming themselves fast fashion 
manufacturers, virtually occupying the entire local low and medium-to-low cost garment production.

The competitive edge of the local garment industry rested in the ability to simultaneously benefit from the advantages offered by the district - ready availability of contractors and raw materials and the image of the district as producer of fashion - and to mobilize transnational networks that facilitated the continuous arrival of workforce from China and the import of part of the raw materials; and in the advantages offered by the highly flexible and off-the-books labor of compatriots in Chinese contracting businesses.

By the mid-2000s, the new productive organization had transformed Prato into the largest fast fashion garment centre in Europe, able to keep up with the frantic changes in the fashion industry and therefore to withstand competition with garments from China. Thus, the new garment center was able to attract buyers from Europe and beyond (Ceccagno, 2003b, 2007b and 2009; Pieraccini, 2008).

Thus, Chinese migrants have played a crucial role in the city's ability to achieve and maintain its competitiveness in the fast fashion industry. Prato is the place in Italy where Chinese migrants' contribution to reshaping the locality is most evident (on migrants development function see Waldinger et al., 1990; Light et al., 1999; Ceccagno, 2007b; Glick Schiller and Caglar, 2011 among others). Their expansive role is visible in the growing importance of this sector in the overall local economy. By 2003, the production of garments and knitwear had increased to the point that - also as an effect of the already ongoing crisis and reduction in production of the textile industry proper (see below) - these businesses represented about $28.3 \%$ of the textile and garment industry firms located in the Prato district and $25 \%$ of the gross total (CCIAA Prato, 2004). According to recent estimates by the local entrepreneurs association, the garment industry's turnover and exports in 2011 amounted to about one third of the total value of turnover and exports by the Prato textile and garment industries together (total turnover $€ 4,599$ millions, total export $€ 2,404$ millions) (Unione industriali Prato, 2012).

The Chinese migrants in Prato have thus strengthened the fast fashion sector in such a way that has contributed to the gradual transformation of what was solely a textile district into a fashion district (Ceccagno, 2007a). However, full economic integration of the two specializations in the industrial district is taking place only partially, given that the textile sector is active mainly at the high to medium level while the Chinese garment centre mainly manufactures low-level fast fashion garments. In 2010 the local chamber of commerce advocated the creation of a 'city of fashion' through the transformation of Prato into 'Europe's fast fashion integrated chain' (Rullani et al., 2010: 44, my translation from Italian). However, the local socio-economic players seem unable to develop and to pursue a solid integration project.

I have shown that Chinese migrants in Prato have also acted as agents of revitalization of part of the local textile industry (Ceccagno, 2009). In fact, the mushrooming of fast fashion activities within the district has pushed growing numbers of Italian textile producers to adapt to the new opportunity and to 
also produce medium to low level fabrics specifically for the local garment producers. This required changes in the quality and type of production, internal reorganization of some productive phases, for instance the elimination of rigorous quality control, and adaptation to the frantic rhythm of the fast fashion. Back in 2004 one local association of small entrepreneurs had estimated that one third of the locally produced textile fabric was purchased by Chinese manufacturers (Confartigianato, 2005). Subsequently, no data has been published on the amount of textile fabric purchased in the Prato ID by fast fashion businesses.

But from 2006, Chinese migrants started buying small textile dyeing and finishing firms, that is those productions in the textile industry that are crucial for the swiftness required in the fast fashion industry. This move has been perceived by some local entrepreneurs as the first steps in the take-over of the ID's core industry. According to some Chinese recently interviewed, three or four Chinese migrants are now operating small textile firms in Prato.

\section{Natives and Migrants in the Garment Industry}

By the end of the century, native apparel manufacturers, who relied on Chinese contractors, lamented on local newspapers that a new trend had emerged whereby Chinese contractors increasingly preferred to work for co-nationals than for native manufacturers. The trend was perceived as a trial of ethnic strength. Chinese migrants did not reply on local media, but when interviewed they very pragmatically stated that lost payments, deception and fraud enacted daily by Italian manufacturers were at the basis of their intra-ethnic preference (for a detailed description see Ceccagno, 2009).

It is estimated that around $80 \%$ of garment businesses in Prato (including contractors and manufacturers) are now owned by Chinese. Sasch (linked to the present Prato major and now closed), Sonia Fortuna (that in 2012 went bankrupt), and Patrizia Pepe are local cases of successful garment firms owned by natives outsourcing the production to Chinese contractors. Other successful Italian garment manufacturers outsourcing to the Chinese in Prato are located in other areas of the country. These are medium level firms, while most of the Chinese manufacturing businesses are low to medium level. Given that since the early 2000s a number of Chinese contractors were already working for wellknown high-level Italian brands, through Italian intermediaries (Ceccagno, 2003b and 2009), the positioning of most Chinese manufacturers at the medium-to-low level is due more to buyers' requirements than to a lack of manufacturing ability. Buyers are mainly street vendors, shops, and medium and large firms with their own brands from all over Europe and beyond.

The year witnessing the expansion of Chinese migrants in the garment industry are also the years during which many Italians closed their businesses. According to the local chamber of commerce, clothing businesses owned by natives in Prato fell from 669 in 2002 to 399 in 2005 . However, the dynamics behind a sharp reduction of businesses owned by natives are complex and partially unclear. First it is unclear whether those that closed down were contracting or manufacturing firms; second, it is unclear whether the reduction in the number of native owned businesses was mainly due to competition 
from Chinese businesses or to other reasons. Researchers have pointed out that in Prato many Italian small contractors have closed because of the lack of interest among younger generations to follow on their parents' footsteps (Ceccagno, 2003a; Spinner, 2005). A similar trend has taken place in other Italian IDs (Hadjimichalis, 2006). As for native manufacturers, interviews that I have conducted in 2004-2006 among Chinese migrants show that it was widespread among small Italian manufacturers the practice of declaring bankrupt and closing their business in order to avoid paying (Chinese) contractors.

In short, a host of different factors contributed to the radical change in Prato: international competition that drove down the profits of manufactures who in turn squeezed down contractors' margins; cost competitiveness of Chinese workshops; a strong push toward self-employment among Chinese migrants as opposed to the lack of interest in the next generation of Italians in working as suppliers. As a result, many native contractors closed and many new Chinese contractors and manufacturers opened their small business, in a context where the local garment industry was dynamic and growing as never before.

\section{The Textile Industry is Sinking while the Garment Industry is Perceived as Thriving}

The industrial district of Prato contributes $25 \%$ of the total Italian exports of woolen products. In the last two decades, the previously wealthy industrial center manufacturing medium to high quality textiles that contributed to the international success of Italian design has been hit hard by global competition.

After a first crisis in the second half of the 1980s - before the arrival of the migrants in Prato -, the textile district experienced another crisis in the years 2000s, with employment and exports declining dramatically. The local chamber of commerce has estimated that in a decade, starting from 2002, about $15-20 \%$ of the local textile productive capacity would have been lost (Rullani et al., 2010). According to more recent data, in the last ten years, the number of textile firms has declined from 5,800 to around 3,000, the number of workers has been cut by half, and a 1.6 billion turnover has been lost (Pieraccini, 2012). Prato is currently experiencing is its worst economic crisis yet (Santini et al., 2011), a crisis that has plunged the city into a state of socio-economic uncertainty and social distress.

The decline of Prato's textile industry - as well as the decline of much of the Italian textile and garment industry - is locally perceived as 'largely induced by global external pressure' (Dei Ottati, 2009b). In actual fact, it is the result of shifts taking place not only at the global, but also at the national and local level. In 1999 the Italian state had officially recognized 199 industrial districts to which various subsides would have been granted. Meanwhile, recurrent depreciations of the national currency had been adopted by the Italian state for fostering the international competitiveness of Italian industry. The introduction of the euro in 2002 put an end to these protectionist practices. By 2005, also the protectionist barriers set up by western countries through the Multi-Fibre Agreement and the Textile and Clothing Agreement had vanished, thus making it possible for countries with lower production costs to further increase their exports (for a detailed discussion of the geopolitical changes at global and 
national level and the subsequent restructuring processes taking place in Italian IDs see Hadjimichalis, 2006). These developments have pushed many in Prato, as in other Italian IDs, to delocalize part of production or all firms to low labor cost countries. Therefore the crisis of the local textile industry is also the result of intensive delocalization processes. Restructuring processes in Italian IDs also include an extensive use of immigrant workers. In Prato, most migrants originating from Albania, Morocco and Pakistan are employed as workers in textile firms, besides being active in the construction industry and in services.

Today the city is exhausted by a state of crisis that it is not able to address and that shows no sign of coming to an end. In the last years, the social atmosphere in Prato has become tense, as many resent the Chinese migrants for being successful in a time when the ID is sinking (see Pieraccini, 2012 among others). The fact that the district's textile industry is sinking while the fast fashion industry is perceived as thriving is used as an empirical evidence of the strong correlation of the two phenomena, as if the growth of the fast fashion industry went to the detriment of the city's core industry.

\section{Is the Fast Fashion Industry still Thriving?}

From the early 1990s on, Chinese businesses, mainly active in garment production, have been steadily growing (Ceccagno, 2003a). They were 479 in 1997, 1,288 in year 2000 and 2,013 in year 2004 (CCIAA Prato, 2005). In 2010, 4,808 Chinese-run businesses were active in Prato (CCIAA Prato, 2012) or 3,750 according a different institutional source (Affaritaliani, 2012). However, if compared with the previous growth, in the last years the growth rate has been declining. In fact, while in 2006 the growth rate was close to 24\%, in 2007 the growth amounted to $17.1 \%$ and decreased to around $13 \%$ in the following two years. A further decline in growth was recorded in $2010(+7.8 \%)$ and 2011 (+6.5\%), according to provisional data in June 2011 (CCIAA Prato, 2011 and 2012). Provisional data for 2011 show that 4,945 Chinese businesses were active during the first six months of the year (CCIAA Prato, 2012). Therefore, official data related to the last two years still present a situation of growth, even if moderate. An alarmingly high mortality and turnover of Chinese-run businesses $151.7 \%$ in 2011 ) is reported by the same source; this issue will be discussed below.

The news that also the Chinese garment industry was hit by the crisis and that an exodus of Chinese migrants from Prato had started has been published in early 2012 (Affaritaliani, 2012) after the local police had discovered that more than 1,000 foreign residents in Prato $-90 \%$ of which were Chinese - had moved to other locations in 2011. But only a few months later, the news that the Chinese operated fashion centre in Prato is hit by the crisis seems quickly forgotten by policy-makers and local media. In August 2012 an article published on the most influential Italian economic newspaper contrasted the 'mayhem' experienced by the Prato's local textile industry - conducted by natives - with the success of 'the ethnic industrial district' created by Chinese migrants and active in the production of garments (Pieraccini, 2012).

My recent fieldwork among Chinese entrepreneurs in Prato shows that a major crisis that touches a growing number of businesses is taking place in Prato since 2011. 


\section{The Real Estate Market Senses the Crisis of the Local Garment Industry}

The first to realize that, after years of severe crisis of the local textile industry, in Prato also the Chinese-run garment industry was hit hard by the crisis have been the real estate agencies and people renting their warehouses to Chinese migrants. Chinese, who used to buy real estate in Prato, do not buy houses anymore, many even sell out their flats to co-nationals; and the competition for being able to rent one of the once much sought-after warehouses in the garment centre is definitely over. Back in the mid-2000, in the Prato ID, Chinese were eager to pay incredibly high sums of money in order to rent a warehouse in the heart of the fast fashion district. At that time up to $€ 300,000$ could be paid, besides the rent, in order take priority over other potential tenants. Now the crisis has completely upset the market prices of warehouses. There is no way of re-selling to other Chinese the priority bought at high prices, since there are no new tenants replacing those that close down. The first to close down their manufacturing businesses were at least able to sell to other Chinese their assets - machineries, office furniture end even textiles. One Chinese explained that in early 2011 a relative of his had sold its assets for $€ 100,000$, thus recovering part of the original investment. But now that many Chinese manufacturers want to get rid of their unproductive businesses, nobody buys other businesses' assets anymore.

\section{Chinese Manufacturers and Contractors in the Garment Industry: Some Numbers}

In 2010, according to the local chamber of commerce, in Prato 3,791 Chinese firm were engaged in productive activities, producing textiles (243), garments $(3,364)$, leather goods (92), furniture (44) and other goods (CCIAA Prato, 2012). Existing data on Chinese migrants' businesses in Prato do not separate manufacturers from contractors. Information on the subject, therefore, only comes from interviews with Chinese entrepreneurs. The first Chinese manufacturers in garment production in Prato opened as early as 1997. In 2006-2007 about 300-350 firms were contracting to fellow Chinese the sewing of garments they designed, cut and sold (Ceccagno, 2007a and 2009). After my recent fieldwork in Prato, it can be estimated that around 900-1,000 Chinese manufacturers were active in the industrial district in early 2011. From then on, the number of manufacturers has been decreasing, it can be estimated that by mid-2012 about 100-200 manufacturers had closed their businesses. Many others who are making no profit at all plan to close soon. Some relocate to other districts in Italy, or look for opportunities in Europe.

According to some interviewed Chinese entrepreneurs, over the last years the increase in the number of manufacturing businesses in the ID did not coincide with an increase in the number of warehouses selling fast fashion garments because, starting from the golden moment in 2005, many new manufacturing businesses were opened in the same premises where a fast fashion manufacturer was already operating. Therefore, data on the number of empty warehouses previously used by Chinese manufacturers in the industrial area would not provide reliable information from which to infer the number of closed businesses. 
According to the interviewed Chinese, in Prato contracting businesses are closing at a more accelerated pace than manufacturing businesses. No reliable data is available on the actual number of contracting businesses that have closed during the last year. One could be tempted to infer that most of the 900 Chinese resident in Prato that were found missing by the local police could be the Chinese contractors that have closed their businesses. However, the traditionally very high territorial mobility of Chinese migrants makes it dangerous to draw such a conclusion.

\section{The Vicious Circle: Police and Administrative Inspections and Chinese Businesses' Reactions}

The reasons behind the recent crisis of the once thriving garment center run by Chinese are manifold and intertwined. Many Chinese migrants, however, are convinced that excessive pressure on Chinese businesses from the local authorities plays a central role in the crisis. With the election of the right-wing local government in 2009 in a traditionally left-wing city, the number and frequency of police and administrative inspections on Chinese businesses and living conditions increased sharply (for an in-depth description see Bracci, forthcoming). These checks are selective in that they are mainly targeted on Chinese businesses. This strategy is the central pillar of the local government approach to Chinese businesses in the city. In different occasions, police controls have been turned into a spectacle, with soldiers patrolling the streets in 2008 and police helicopters repeatedly flying over the areas where checks were conducted in late 2011. According to one member of the local government, the aim is to reduce the number of Chinese living and working in Prato. It is unclear how the city and industrial district would benefit from a reduction of the number of Chinese migrants and their activities.

According to some natives that do business with the Chinese, the continuous raids stepped up against the Chinese penalize all Chinese businesses, including those that operate legally. The manager of a bank branch in Prato declared that less foreign buyers come to Prato now, discouraged by the widespread checks (Pfaender, 2010). Besides, fines imposed on irregularities are perceived as too heavy, especially when the Chinese migrants operate small businesses. Chinese migrants feel vulnerable and unable to sustain the relative affluence they have gained through hard work over the years.

This strategy adopted by the local government is not without consequences, and some are probably unexpected. The weightier administrative inspections and fines imposed on businesses, the higher the number of Chinese people that chose to enter complete illegality and stop paying for everything.

In fact, as a reaction to administrative checks and fines, a growing number of Chinese manufacturers find name-lenders among Chinese elders or people that intend to end their migratory experience and return to China. These businesses avoid paying taxes and levies, including personal income tax, value added tax and local taxes, including the tax for garbage collection. As a rule, these businesses close down after only one year, and reopen the activity under a different lent name. The business director - which is the actual owner of the business - is the same in the new business. 
Situation of name-lenders are not completely new among the Chinese businesses in Prato. Researchers have highlighted cases of people that appointed one of their workers as the (fake) boss of the business so that they could avoid the risk of being convicted on a charge of using undocumented workers (Ceccagno and Rastrelli, 2008). According to Pieraccini (2008), in the mid-2000s many Chinese firms closed down immediately after inspection in order to avoid paying taxes and fines. Now, according to some interviewees, the situation is much more radicalized and widespread among Chinese entrepreneurs.

The choice of becoming full unlawful, however, is not appreciated by many other Chinese, even if they perceive it as somehow induced by the new policies adopted at local level. Name-lenders have been termed 'predators' by some interviewed Chinese who explained that these migrants' behavior has a tragic effect not only on the local economy but also on all other Chinese manufacturers who more or less regularly pay taxes and therefore face higher productive costs than people that choose full tax evasion - and thus are forced to sell their garments at higher prices.

Some Chinese interviewees argue that a vicious circle has been started by the local government that will eventually destroy the Chinese-run economy. They point out that something similar has happened years ago in Paris, after harsh controls on Chinese garments' contractor had been conducted by the local government.

The option of reopening the business under a new name seems available only to manufacturers who, as a general rule, are wealthy enough to be able to pay co-ethnics as name-lenders. Contractors cannot afford to look for name-lenders and when administrative checks find them irregular and they are imposed heavy fines, they often cannot do anything else than to close their business permanently.

This situation shows that the Chinese community is far from being as monolithic as many depict it. On the contrary, interests within the group sharing the national origin can be conflicting and choices made by some have a negative impact on and are therefore strongly disapproved by others.

\section{How to Read the Mortality of Chinese Businesses?}

Data on Chinese businesses turnover and mortality are alarming. According to the chamber of commerce, even though in 2010 the number of businesses was increasing, a total of 1,000 Chinese businesses had closed, and 600 more businesses run by foreigners have closed down in the first six months of 2011. The percentage of Chinese businesses closing down has reached $22 \%$ of the total (table 1). Besides, by 2011, 48\% of all Chinese businesses had been active for no more than two years. The turnover for Chinese businesses has reached $51.7 \%$ during the first six months of 2011 (CCIAA Prato, 2012). 
Table 1: Province of Prato: Opening and closing businesses and turnover of local businesses (2010)

\begin{tabular}{|l|l|l|l|l|}
\hline & $\begin{array}{l}\text { Opening } \\
\text { businesses }\end{array}$ & $\begin{array}{l}\text { losing } \\
\text { businesses }\end{array}$ & $\begin{array}{l}\text { Growth } \\
\text { percentage }\end{array}$ & Turnover \\
\hline Chinese & 29.9 & 21.6 & 8.3 & 51.5 \\
\hline All Foreigners & 24.8 & 17.3 & 7.5 & 42.1 \\
\hline Native businesses* & 6.6 & 7.4 & -0.8 & 14.0 \\
\hline Total & 10.7 & 9.6 & 1,1 & 20.3 \\
\hline
\end{tabular}

* Native businesses are inferred by deducting from the total number of businesses registered at the Chamber of commerce those that are not conducted by foreigners. Source: CCIAA Prato on data from Infocamere (2011).

According to the interviewed Chinese, the number of businesses that close in order to avoid payments and reopen under a new name is so high and the phenomenon so widespread that among the Chinese in Prato a new name has been coined for it. 'Natural death' is the name for those that close down because of the usual problems that cause the death of businesses, while for the short-term businesses that lend names, Chinese migrants in Prato speak of 'unnatural death'.

Given this state of affairs, official data on mortality of Chinese businesses in Prato do not reflect the actual market dynamics and the factual situation but hide a situation that is not fully perceived and therefore addressed.

\section{Is Migration from China Coming to an End?}

The increased checks and heavy fines imposed on Chinese businesses and the reaction of many Chinese businesses that choose to operate completely underground is only one element that aggravates a deteriorated situation. In fact, the crisis of the Chinese garment industry in Prato is a complex one, linked as it is to global changes, to the economic crisis in Europe and worsened by strategies adopted at the local level.

Among global changes, the central one is linked to a shift in global migration dynamics that affects the local Chinese garment centre.

In the past 30 years, China has progressively become a crucial hub of the new global migration order. China's political reforms and economic development have given rise to massive flows of domestic migration and international out-migration. Europe has been perceived by the new Chinese migrants as a chessboard of opportunities along which they could move in search for the best opportunities (Ceccagno, 2003a; Pieke et al., 2004). In Italy, starting from the 1980s opportunities for a low-skilled labor force opened for new migrants, especially in industrial districts. A succession of unskilled workers originating almost exclusively from the southeastern Chinese province of Zhejiang started arriving in mid-1980s, later followed by arrivals from Fujian province and from China's northeastern provinces. Especially from the 1990s, the global economic integra- 
tion of China has created new opportunities for Chinese to migrate by opening up international consumer markets. Many migrants operate as importers, wholesalers and retailers of made in China goods in receiving countries. In Italy manufacturing activities in IDs and marketing of cheap goods imported from China coexist. In 2004 the Chinese businesses active in trade and services have outnumbered the Chinese businesses active in manufacturing activities (Ceccagno, 2007b).

More recently some have documented that China is rapidly becoming an important destination of international immigration (Haugen, 2012; Pieke, 2012). The continued growth of its economy and its gradual transition to an urban, service-based economy suggest that China will soon shift from a country of internal migration and international emigration to a major immigration country. Researchers argue that economic and social development combined to demographic trends make it impossible to continue rely on an inexhaustible supply of labor migrants for the lower-end jobs in urban manufacturing, construction and services (Pieke, 2012).

These changes are at the basis of a reduction in out-migration from China, at least for some types of migrants.

Researchers focusing on the situation in the US have shown that a substantial number of highly skilled immigrants have started returning to their home countries, including migrants from China and India who return to their home countries because they perceive that there are greater economic and professional opportunities for them there (Wadhwa et al., 2009).

There is no available data or analysis on a decline in the arrival of Chinese migrants to Europe. According to a Chinese source, 93\% of migrants originating from the Wenzhou area, Zhejiang province are found in Europe, with $55 \%$ in Italy ( $\mathrm{Wu}, 2009)$. The vast majority of the Chinese in Italy originate from Zhejiang province, and in particular from the Wenzhou area. While domestic labor migration is expected to come to an end soon in China, international labor migration from Wenzhou - by now a vibrant economic centre, also thanks to the contribution of its migrants - has probably already come to a halt. According to the Chinese interviewed in Prato, the time of continuous arrival of migrants from China to Italy has come to an end. Migration is no more perceived as the best locally available option for workers dreaming of becoming entrepreneurs as it was back in the 1980s and early 1990s in the sending areas in Zhejiang and Fujian (Pieke et al., 2004). In particular, Italy seems not to be attractive in a time of crisis. More data and research on the subject are needed.

\section{Impact of the End of Labor Migration from China on the Working Arrangements in Prato}

In the Chinese-run businesses in Prato, both owners and workers are Chinese. The severe reduction in the number of available Chinese workforce heavily contributes to altering in more than one way the previous existing working arrangements.

First, it undermines the swiftness that had made possible for garment manufacturers in Prato to withstand competition with cheap imports from China and 
other countries. A key feature that has heavily contributed to the success of the Chinese garment industry in Prato is the fact that it has been able to produce garments with the speed necessary for the frantic changes in shape and colors demanded by fashion (Ceccagno, 2009). The continuous arrival from China of a highly flexible and territorially mobile workforce has been a central asset contributing to the Prato garment centre competitive edge. In fact in the Chinese garment centre the need to rely upon a large productive capacity during the periods when high volume of orders were received has been fulfilled counting exactly on workers readiness to move to other workshops, if necessary in another city, for a few days or weeks. With a reduced workforce, orders cannot be completed as swiftly as in the past.

Second, labor supply does not meet labor demand anymore. Workshops mainly need skilled workers but most of the available workforce is made of unskilled workers originating from China's northeastern provinces (Dongbei). ${ }^{3}$

In Chinese contracting businesses active in Prato and in Italy native-place networks play a crucial role. In fact, in order to become skilled a worker needs to count on a network whose members accept to temporarily reduce their income - skilled workers are paid by piece - in order to train the newcomer. Different opportunity structures have been available in Chinese workshops in Italy for Chinese with different areas of origin (Ceccagno, 2003a and 2007a; Pieke et al., 2004; Ceccagno and Rastrelli, 2008). In the 1980s and 1990s, upon arrival, most Chinese originating from Zhejiang and Fujian counted on native-place networks that helped them to reach the position of skilled workers in a relatively short span of time. At that time, the bottom position of zagong (odd jobs, from cleaning to cutting loose threads from clothes) had been a temporary occupation for most newly arrived migrants.

From the end of the 1990s, instead, in workshops mainly run by Zhejianese where skilled workers originated from Zhejiang and Fujian, migrants from Dongbei often did not receive the needed training to become skilled. This produced a situation in which they often ended up stuck in the position of zagong and had the weakest bargaining positions (Ceccagno and Rastrelli, 2008). Another typical occupation for migrants originating from China's northeastern provinces is as cutters in the manufacturing businesses. Garment cutting is considered a physically demanding job, and therefore not so sought-after. A situation where upward mobility of workers is linked to home region's networks has been found also in the factories employing migrant workers in Southern China (Pun, 2005).

Now that the ethnic economy in Prato suffers from a lack of skilled workers, migrants from Dongbei are not able to take advantage of the new opportunity. This in turn has a negative impact also on the workshops that cannot count on skilled workers as they did in the past.

Third, according to many Chinese migrants, the situation depicted above results in a new and different relative bargaining power of employers and skilled

3 Migrants from China's northeastern provinces are the latecomers, arriving in Italy only starting from the late 1990s. They originate mainly from large urban centers in China. Many of them are women, many of which have been involved in the Chinese prostitution ring. 
workers. Some interviewees declared that the labor demand and supply is so distorted by the lack of experienced workers that skilled workers are now in a position of strength that enables them to dictate conditions not only in monetary terms but also in terms of board and lodging (many contractors workshops are also sleep-in places). This statement, if confirmed by further fieldwork, could hint at a significant departure from previously existing industrial relations in Chinese firms. In fact, researchers have highlighted that workers in Chinese workshops were highly vulnerable and employers had a considerable power over them (Ceccagno and Omodeo, 1997; Ceccagno, 2007a). On the basis of a fieldwork conducted in 2006 among Chinese businesses in the Veneto region, Wu and Sheehan (2011) document the poor working conditions in Chinese owned factories and the total dependency of workers upon Chinese employers. They argue that the main source of the vulnerability of Chinese migrant workers in Italy is their social isolation, related to the type of premises in which they work. Montenero (2011) argues that Chinese sweatshops are places where human trafficking, and child and forced labor are found (but for a critique of the reading of Chinese workshops in Italy as places where trafficking and forced labor take place, see Ceccagno and Rastrelli, 2008; Ceccagno, Rastrelli and Salvati, 2010). It is therefore crucial to conduct further research on this issue in order to find out if and in which ways the relative strength of employers and workers is changing. In particular, the fact that workshops also employ undocumented migrants does not leave much room for theorizing a significant shift of the power balance in favor of (skilled) workers.

\section{The Downsizing of the Fast Fashion Center in Prato}

As anticipated, the crisis of the local garment industry is also linked to the acute economic crisis that many European countries are experiencing. Chinese in Prato explain that with the aggravation of the crisis, the purchasing power of clients in Europe has declined significantly. In particular, buyers from countries hit hard by the crisis, such as Spain and Greece that in the last years had been among the main clients of the garment centre in Prato, have now almost disappeared. But, as seen above, reduced orders are also the result of the much advertised raids against Chinese manufacturers.

Relations of mutual trust based on shared place of origin are strained in the time of crisis. Some interviewed Chinese explained that with the crisis in Europe many clients from Madrid and Barcelona have not finalized the payment of the goods received. These clients are mainly Chinese. In the past, the shared place of origin had often helped create a relationship of trust between seller and buyer, to the point that till recently goods were sent without payment in advance by bank transfer. With some European countries hit hard by the economic crisis, however, trust is something people can afford less and less.

On the whole, the impact of the crisis on the intertwined destiny of all those involved in the different manufacturing phases of the local garment industry is evident. Now that some competitive advantages previously guaranteed by migration patterns, the ethnic environment and a more tolerant attitude towards illegality and tax evasion are fading away, every segment of the complex machine is shaken when one or more segments do not function properly as they did in the past. 
I have shown that Chinese manufacturers in Prato were able to reduce to a minimum the so-called 'time to market' by spreading the production over more workshops than actually needed also during the slack season, so that a relationship was created and maintained with as many contractors as possible that could be ready to speed up assembly of garments during the peak season (Ceccagno, 2009). As the crisis pushes a growing number of contractors to close down, manufacturers may meet with problems in guaranteeing their well-known ability to fulfill orders swiftly during the high season.

However, part of the businesses that are closing is simply not fit to the fashion industry. Those businesses that have not been able to increase the variety of garments and diversifying the clientele end up being more and more marginal. This is the case of a number of small family run businesses that were pulled by the driving force of the expanding Chinese-run garment centre in the first years 2000s, when there seemed to be room for almost everybody. Now however, when competition is fiercer, they are the first to be expulsed from the market.

Now more than before, competition among Chinese businesses in Prato has become a deadly price competition. This pattern is strikingly similar to the one taking place among native owned small firms: in both cases, internal competition is primarily price competition that hits the weakest categories, i.e. small firms and contractors. Hadjimichalis (2006) points out that this kind of competition has prevailed in Italian districts in the last years and it has introduced conflicts and tensions that block the traditional mechanism of coordination through cooperation and trust.

In conclusion, many and different reasons concur to the current crisis of the garment center. The garment centre as it had been created in the late 1990s and especially in the years 2000 had the potential to withstand the competition with garments from low labor costs countries, including China. Import of garment from China itself has not proved to be disruptive for the fast fashion made in Prato. As I have pointed out, the centre in Prato could rely on higher fashion content than cheaper garments from China (Ceccagno, 2009). Retail shops owned by Chinese in Italy and in other European countries, from Spain to Hungary, display side by side garments imported from China together with garments made in Prato, well aware that they respond to clients' different expectations: lower prices in the case of imports from China and higher fashion content at reasonable prices in the case of garments made in Prato. This has made the Prato centre attractive also for big retailers such as Zara and H\&M.

On the long run, unless a less ethnocentric approach was adopted in Chinese owned workshops by migrants and their offspring, the drying up of migration flows from China alone could prove a central hindrance to the further development of the fast fashion centre. However, other factors, and in particular the crisis in Europe that has a tremendous impact on garment consumption and the aggressive attitude of the local institutions are central in downsizing and inhibiting the further development of this local industry. And it is likely that the present downsizing will be more dangerous for the future competitiveness of the garment centre in Prato than competition from China. 


\section{Why is the Crisis of the Chinese Garment Center not Acknowledged?}

Italian IDs have been depicted as cohesive socio-economic milieus. Many ID scholars contend that at the basis of the success of the Italian IDs is the active cooperative attitude of all the actors operating in the district, including entrepreneurs, unions and local institutions (Piore and Sabel, 1984). One fundamental feature of the industrial district is the respect of the implicit norms of reciprocal cooperation, or the 'code of the district' (Becattini, 1990; Brusco, 1999). The 'code of the district' therefore is presented by ID scholars as heavily contributing to the proper functioning of the district processes of division of labor between firms and generating competitive advantages for its members. In particular, ID scholars in Prato argue that this pervasive 'code of the district' has both been molded by and has contributed to the spread and strengthening of a local individual and collective identity proactively reinforced by local institutions. According to Dei Ottati (2000: 12), 'a sense of local membership spread, which became prominent compared to other identities, for example that of class belonging'.

Local ID scholars in Prato stigmatize Chinese migrants and their economic activities. They posit that the institutional equilibrium of the ID has disappeared and that a new set of implicit norms and shared values has emerged instead, 'the socio-cultural system' of the newly arrived Chinese migrants (Dei Ottati, 2009). Much conceptualization developed by the main stakeholders and ID scholars in Prato rests on the postulate that Chinese businesses are dis-embedded and have been growing in isolation from the local industrial system - even though largely benefiting from it and from the ready to use 'made in Italy' informal brand. From the mid-1990s on, even before they were able to also become manufacturers, Chinese migrants have been accused of having created a 'district within the district' (Toccafondi, 2005; Pieraccini, 2008; Bellandi et al., 2011, among others). Chinese contracting workshops and manufacturers are depicted as 'a threat, at first to local subcontractors, and then also to final firms of the industry in which they operate' (Dei Ottati, 2009: 36). After the Chinese started to buy small dyeing and finishing firm sold out by natives, they have been depicted as entering 'into direct competition with part of the final firms of the main industry of the district'. This perception is echoed by journalists, for instance in a book published by the national entrepreneurs association, Prato is depicted as besieged by Chinese migrants (Pieraccini, 2008).

The social impact of Chinese immigrants is depicted in harsher terms. According to Dei Ottati (2009a: 36-37), they have changed 'the physiognomy of the district as a whole: the urban and industrial landscape itself... becomes transformed to the point of becoming alien to the local population'. Moreover, 'the expansion of the Chinese community introduces conflict into the very heart of the local population'.

However, elements that are ascribed to the Chinese as peculiar of their 'socio-cultural code' such as the existence of an informal sector, unpaid family labor and the like are part and parcel of the reality of Italian IDs. Hadjimichalis (2006) questions the celebrated characteristics of the IDs of the past arguing that the grand narratives of some scholars theorizing on Italian IDs leave in the dark the existence in the ID firms of informal economy, poor working and safety conditions, long working hours and low pay. 
The confrontational attitude towards Chinese migrants emerging from much research conducted by IDs scholars can be understood only against a complex national and local background. Any assessment of migrants contribution to the restructuring of the locality in the case of the Prato industrial district is shadowed by anger and fears that have been mounting at the national level against China and its stiff competition in the productive sectors in which Italy was once a world leader. The tense atmosphere is palpable and also reflected in the Italian cultural production. The acclaimed movie 'The arrival of Wang', where tentacled aliens who only speak Chinese destroy planet Hearth, is an overt metaphor of how China is perceived in Italy.

Prato is the place in Italy where fears, widespread at national level, of being destroyed by China are compounded with fears that Chinese migrants in Prato are taking over the district. A Chinese 'dual challenge' is perceived as hanging over the district - from China and from its migrants based in the ID. In the words of one ID scholar in Prato 'the formation of an ethnic economy brings global pressure directly into the heart of the district, into both its economy and its society (Dei Ottati, 2009a: 37). This is also the narrative in Story of my people (Nesi, 2010) - the national Strega literary prize winner in 2011, written by a Prato former entrepreneur -, where neoliberalism, China and Chinese migrants are blamed for the crisis in Prato. Moreover, the ID's dominant discourse depicts the transnational positioning and global relational assets of Chinese migrants as part of the compounded pressure originating from China and its migrants that weighs on the ID. But the attitude towards this competitive advantage is ambivalent. While describing Chinese migrants trans-local and transnational networks as a threat to the locality, ID scholars in Prato argue that only by making this competitive advantage available to local entrepreneurs would the Chinese contribute to restoring the lost social cohesion (Dei Ottati, 2009a: 38).

By blaming the Chinese migrants for the crisis of the district, the hegemonic discourse has ethnicized the social tensions and conflicts of a locality that is unable to find a way out of the crisis. Mistrust and acrimony are so widespread by now that politicians and institutions in Prato fail to acknowledge the disruptive crisis of the Chinese-run garment industry and to address it.

\section{The Rescaling of the City and the Assessment of Migrants' Role in it}

Prato, as every other city, has been restructured by processes that are global and local, and has been forced to reimaging itself. Chinese migrants in Prato have been themselves constitutive of the repositioning struggles of the city. In Prato, the garment industry has not balanced the crisis of the preexisting core industry. Also, the coincidence in the rise of Chinese activities and the concurrent crisis of the main industry of the district, that has plunged the city into a state of socio-economic uncertainty, contributes to overshadowing the role of Chinese migrants in the rescaling of the city. Migrants' contribution to the remaking and competitive repositioning of cities is often downplayed, distorted and denied. In the case of Prato, the contribution of Chinese migrants to reframing the city's socio-economic landscape is contested and rejected by the main stakeholders. 
The negative assessment is constructed as multi-layered. Chinese migrants' affluence is perceived and narrated as only circulating among people sharing the same national origin, and therefore not contributing to the more general wellbeing of the locality. Therefore a concentration of migrants sharing the same origin that become affluent in a time of collective impoverishment in the city may be argued by the dominant discourse as detrimental for the restructuring of the locality. By now the Chinese in Prato are perceived and depicted as more affluent than natives. Be it true or only imagined, this disparity of affluence is at odds with the prevailing discourse in Italy whereby migrants are represented as poor, uneducated and employed as a workforce by Italian entrepreneurs for the least desired tasks (Ambrosini, 2001). An implied consequence of this perception of Chinese as an unduly rich community is the high tolerance by local institutions for daily acts of robbery against Chinese. Chinese walking down the streets, or working in workshops or even in their houses are attacked and robbed daily by migrants originating from North Africa and, with less frequency, even by Italians.

But the dominant discourse in Prato goes further and narrates the development of the garment centre as detrimental to the city and its core industry. The strong discontent originating from the severe downscaling of the ID as global competitor has been channelled in a way that Chinese migrants are blamed for the impoverishment of the city and its loss of international relevance. Such a process of scapegoating Chinese migrants is fuelled by the two different discourses mentioned above: the perception - widespread at national and local level - that the migrants' place of origin is the main cause for the downscaling of national exports; and the 'dual challenge' narrative whereby China and its migrants are united in conducting an attack on the very heart of the locality. Therefore, it can be argued that the way in which the migrants' country of origin is perceived in the receiving area may have a tremendous impact on the natives' narrative on the migrants' contribution to the rescaling of the locality, especially when the migrants' country of origin is depicted as a powerful country and a fierce competitor responsible for the downsizing of the local economy.

\section{Conclusions}

This paper documents and analyzes the multi-layered crisis of the Chinese garment centre in Prato. The crisis is the result of the combination of dynamics taking place simultaneously at global, national and local level. Dramatic changes in the arrangements within Chinese workshops, mainly dictated by global shifts in international migration patterns, are compounded with the fierce economic crisis in Europe and a reduced tolerance at local level for off-the-book practices in Chinese businesses. These concomitant dynamics are putting a serious strain on the garment centre and risk to slim down an industry that has brought affluence to the city, even though it has not prevented its decline.

In particular, for the first time this paper documents the ongoing drastic changes in working arrangements in Chinese workshops. These changes may have a strong impact on the future of the local fast fashion industry, once perfectly oiled by the constant arrival of new migrants eager to try their fortune in the workshops run by co-nationals. 
This paper also discusses the different shades of the multi-layered dominant discourse on Chinese migrants' contribution to the reshaping of the ID. The fact that the migrants' country of origin is China, a country increasingly held responsible for great globalization damages, seems to justify aggressive tones and punitive policies against them. Here, again, the case of Prato yields new insights into the interplay of scales - global, national, and local - in the complex dynamics between migrants and the locality. Frustration and anger against China widespread at national level in Italy help explain why in Prato not only industrialists but also different groups of the populace have interiorized the dominant discourse that depicts the Chinese migrants as detrimental to the ID.

Prato could therefore be considered an exemplary case showing that an axiom is now widely accepted that considers Chinese migrants as the long arm of the Chinese state aiming at destroying national and local economies. This could also be the case in other countries. A tentative generalization can therefore be put forth: in a global context where diasporas are more and more depicted as part and parcel of their country of origin's transnational strategies, migrants will increasingly bear the burden of perceptions and dominant discourses at global, national, and local level about their home country.

This paper highlights something often disregarded in migration theory that is the existence of strongly conflicting interests among migrants (on conflict of interests between migrant employers and workers, see Wu and Liu, 2012). Different places of origin in China and the time of settlement in Italy have engendered different working opportunities for Chinese migrants in Prato. Besides, choices made by some are detrimental and therefore contested by other Chinese.

The hegemonic discourse in Prato depicts the ongoing local dynamics in terms of native/Chinese migrant polarization that also results in different future perspectives for natives and Chinese migrants in a time of crisis (see Dei Ottati, 2009a). This article shows that the interactions between natives and Chinese migrants in the local economic environment are multifarious. Even if the local government has not yet acknowledged the crisis of the Chinese-run garment industry, many natives, including people renting flats and warehouses to Chinese, textile salespersons and stylists and also native entrepreneurs in the textile industry, banks and real estate agencies are affected or will be affected soon by the new trend in the garment centre.

\section{References}

Affaritaliani.it (2012) La fuga dei cinesi diventa un incubo. Prato, il tessile è in crisi, Affaritaliani.it, [online] last checked on 07/06/2012. URL: http://affaritaliani. libero.it/economia/prati-crisi-del-tessile030112

Ambrosini Maurizio (2001) La fatica di integrarsi. Immigrati e lavoro in Italia, Bologna, II Mulino, $211 \mathrm{p}$.

Becattini Giacomo (2000) II bruco e la farfalla. Prato: una storia esemplare dell'Italia dei distretti, Firenze, Le Monnier, 252 p.

Becattini Giacomo (1990) The Marshallian industrial district as a socio-economic notion, in Frank Pyke, Becattini Giacomo and Werner Sengenberger Eds., Industrial districts and inter-firm co-operation in Italy, Geneve, ILO, pp. 35-71. 
Bellandi Marco, Caloffi Annalisa e Toccafondi Daniela (2010) Riaggiustamento delle rete distrettuali e differenziazione dei percorsi di reazione alla crisi di mercato, in Alberto Zazzaro Ed., Reti di imprese e territorio: soluzioni alla crisi o vincoli alla crescita?, Bologna, II Mulino, pp. 49-76.

Bracci Fabio (2012) The 'Chinese Deviant': Building the Perfect Enemy in a Local Arena, in Emma Bell Ed., No Borders: Immigration and the Politics of Fear, Chambéry, Éditions de I'Université de Savoie, pp. 97-116.

Brusco Sebastiano (1999) The Rules of the Game in Industrial Districts, in Anna Grandori Ed., Organization and Industrial Competitiveness, London, Routledge, pp. 17-40.

Borsari Stefano, Ceccagno Antonella, Gallo Anna e Gaudino Sara (2006) I Cinesi e gli altri, Bologna, Spinner, 35 p.

CCIAA Prato (2012) L'imprenditoria straniera in provincia di Prato, [online] last checked on 10/01/2013. URL: http://www.po.camcom.it/doc/public/2012/ stranieri_11.pdf

CCIAA Prato (2011) L'imprenditoria straniera in provincia di Prato, [online] last checked on 10/01/2013. URL: http://www.po.camcom.it/doc/public/2011/ stranieri_10.pdf

CCIAA Prato (2004) 1994-2004: da X Anni Regista del Sistema Economico Pratese, Prato, unpublished volume.

Ceccagno Antonella (2009) Chinese Migrants as Apparel Manufacturers in an Era of Perishable Global Fashion: New Fashion Scenarios in Prato, in Graeme Johanson, Russel Smyth and Rebecca French Eds., Living Outside the Walls: The Chinese in Prato, Cambridge, Cambridge Scholars Press, pp. 42-74.

Ceccagno Antonella (2007a) Compressing Personal Time: Ethnicity and Gender within a Chinese Niche in Italy, Journal of Ethnic and Migration Studies, 33 (4), pp. 635-654.

Ceccagno Antonella (2007b) The Chinese in Italy at a Crossroads: The Economic Crisis, in Mette Thunø Ed., Beyond Chinatown, Copenhagen, NIAS, pp. 115-136.

Ceccagno Antonella (2003a) New Chinese Migrants in Italy, International Migration, 41 (3), pp. 187-213.

Ceccagno Antonella (2003b), Le migrazioni dalla Cina verso I'Italia e L'Europa nell'epoca della globalizzazione, in Antonella Ceccagno Ed., Migranti a Prato. II distretto tessile multietnico, Milano/Roma, FrancoAngeli, pp. 25-68.

Ceccagno Antonella and Omodeo Maria (1997) Gli effetti del Decreto legge 489/95 sui cinesi di Prato, in Antonella Ceccagno Ed., II Caso delle Comunità Cinesi, Roma, Armando, pp. 59-68.

Ceccagno Antonella and Rastrelli Renzo (2008) Ombre cinesi? Dinamiche migratorie della diaspora cinese in Italia, Roma, Carocci, 166 p.

Ceccagno Antonella, Rastrelli Renzo and Salvati Alessandra (2010) Exploitation of Chinese Immigrants in Italy, inYun Gao Ed., Concealed Chains. Labour Exploitation and Chinese Migrants in Europe, Geneva, International Labour Office, pp. 89-138.

Colombi Matteo (2001) L'industria dell'abbigliamento nel distretto di Prato, in Monica Baracchi, Daniela Bigarelli, Matteo Colombi e Armando Dei Eds., Modelli territoriali e modelli settoriali. Un'analisi della struttura produttiva del tessile abbigliamento in Toscana, Torino, Rosenberg \& Seller, pp. 77-100. 
Comune di Prato (2012) Ufficio di statistica, [online] last checked on 10/01/2013. URL: http://statistica.comune.prato.it

Confartigianato pratese (2005) Vivere insieme. Esercizi di conoscenza, tentative di comprensione, prove di convivenza, Prato, unpublished report.

Dei Ottati Gabi (2009a) Italian Industrial Districts and the Dual Chinese Challenge, in Graeme Johanson, Russel Smyth and Rebecca French Eds., Living Outside the Walls: The Chinese in Prato, Cambridge, Cambridge Scholars Press, pp. 26-42.

Dei Ottati Gabi (2009b) An Industrial District Facing the Challenges of Globalization: Prato Today, European Planning Studies, 17 (12), pp. 1817-1835.

Dei Ottati Gabi (2000) Exit, Voice and Loyalty in the Industrial District: the Case of Prato, [online] last checked on 10/01/2013. URL: http://www.cbr.cam.ac.uk/pdf/ wp175.pdf

Glick Schiller Nina and Çaglar Ayse (Eds.) (2011) Locating Migration. Rescaling Cities and Migrants, Ithaca and London, Cornell University Press, 176 p.

Glick Schiller Nina and Çaglar Ayse (2008) Migrant Incorporation and City Scale: Towards aTheory of Locality in Migration Studies, Willy Brandt Series of Working Papers in International Migration and Ethnic Relations, 2 (07).

Hadjimichalis Costis (2006) The End of Third Italy As We Knew It?, Antipode, 38 (1), pp. 82-106.

Haugen Heidi Østbø (2012) Nigerians in China: A Second State of Immobility, International Migration, 50 (2), pp. 65-80.

Light Ivan, Bernard Richard and Kim Rebecca (1999) The immigrant economy in the garment industry of Los Angeles, International Migration Review, 33 (1), pp. 5-25.

Montenero Jeronimo (2011) Neoliberal Fashion: The Political Economy of Sweatshops in Europe and Latin America, Furham theses, Durham University, [online] last checked on 10/01/2013. URL: http://etheses.dur.ac.uk/3205/

Nesi Edoardo (2011) Storia della mia gente, Milano, Bompiani, 168 p.

Pfaender Matthias (2010) Se anche i cinesi di Prato sentono la crisi, [online] last checked on 10/10/2012. URL: http://www.ilgiornale.it/news/se-anche-i-cinesiprato-sentono-crisi.html

Pieke Frank N. (2012) Immigrant China, Modern China, 38 (40), pp. 41-77.

Pieke Frank N., Nyíri Pal, Thunø Mette and Ceccagno Antonella (2004) Transnational Chinese. Fujianese Migrants in Europe, Stanford, Stanford University Press, 272 p.

Pieraccini Silvia (2012) II tessile di Prato e il dilemma dell'integrazione con i cinesi, I/ sole 24ore online, [online] last checked on 10/01/2013. URL: http://www. ilsole24ore.com/art/impresa-e-territori/2012-08-10/tessile-prato-dilemma-integrazione-064440.shtml?uuid=Ab3XuDMG

Pieraccini Silvia (2008) L'assedio cinese, Milano, Gruppo24Ore, 109 p.

Piore Michael J. and Sabel Charles F. (1984) The Second Industrial Divide, New York, Basic Books, 355 p. 
Pun Ngai (2005) Made in China. Women factory workers in a global workplace, Durham/London, Duke University Press; Hong Kong, Hong Kong University Press, $240 \mathrm{p}$.

Pyke Frank, Becattini Giacomo and Sengenberger Werner (Eds.) (1990) Industrial districts and inter-firm co-operation in Italy, Geneve, ILO, 244 p.

Rastrelli Renzo (2003) L'immigrazione a Prato fra società, istituzioni ed economía, in Antonella Ceccagno Ed., Migranti a Prato. II distretto tessile multietnico, Milano, FrancoAngeli, pp. 69-104.

Rullani Enzo, Tinagli Irene, Trigilia Carlo and Paolazzi Luca (Eds) (2010) Prato in progress. Alla ricerca di alternative strategiche condivise per l'economia postcrisi, [online] last checked on 10/01/2013. URL: http://www.po.camcom.it/doc/ public/2010/pratoinprogress.pdf

Santini Cristina, Rabino Samuel and Zanni Lorenzo (2011) Chinese immigrants socio-economic enclave in an Italian industrial district: the case of Prato, World Review of Entrepreneurship, Management and Sustainable Development, 7 (1), pp. 30-51.

Spinner (2005) Economia del Laboratorio T/A Cinese in Emilia Romagna, Bologna, unpublished report.

Toccafondi Daniela (2005) Ombre cinesi nel distretto di Prato, Economia e management, 5, pp. 81-95.

Unione Industriali Prato (2012) // distretto pratese in pillole, [online] last checked on 10/01/2013. URL: http://www.ui.prato.it/unionedigitale/v2/areastudi/il\%20 distretto\%20pratese\%20in\%20pillole.pdf

Wadhwa Vivek, Saxenian AnnaLee, Freeman Richard B. and Gereffi Gari (2009) America's Loss is the World's Gain: America's New Immigrant Entrepreneurs, [online] last checked on 10/01/2013. URL: http://dx.doi.org/10.2139/ssrn.1348616

Waldinger Roger,Aldrich Howard andWard Robin (Eds.) (1990) Ethnic Entrepreneurs: Immigrant Businesses in Industrial Societies, Newbury Park, CA, Sage, 226 p.

Wu Bin (2009) Chinese migration and Wenzhou's development, in Graeme Johanson, Russel Smyth and Rebecca French Eds., Living Outside the Walls: The Chinese in Prato, Cambridge, Cambridge Scholars Press, pp. 238-260.

Wu Bin and Liu Hong (2012) Bringing Class Back In: Class Consciousness and Solidarity amongst Chinese Migrant Workers in Italy and the UK, Ethnic and Racial Studies, DOI: 10.1080/01419870.2012.715660.

Wu Bin and Sheehan Jackie (2011) Globalization and Vulnerability of Chinese Migrant Workers in Italy: empirical evidence on working conditions and their consequences, Journal of Contemporary China, 20 (68), pp. 135-152.

Yu Zhou (2002) New York: Caught under the Fashion Runway, in Jan Rath Ed., Unravelling the Rag Trade. Immigrant Entrepreneurship in Seven World Cities, Oxford and New York, Berg, pp. 113-133. 


\section{Antonella Ceccagno}

\section{The Hidden Crisis: The Prato Industrial District and the Once Thriving Chinese Garment Industry}

This paper discusses the ways in which Chinese migrants and the city/ID of Prato together mutually constitute the local in the framework of global and national dynamics. It aims to document and explain the dynamics taking place in Prato, Italy at a time when its garment industry, mainly run by Chinese migrants, is confronted with global changes and restrictive local policies that threaten its very existence. Glick Schiller and Caglar (2011) suggest that studies of migrant pathways of incorporation in cities impoverished within global restructuring can contribute to different analysis of the relationship between migrants and cities. This article contends that Prato is an exemplary case that yields new insights into the interplay of scales global, national, and local - in the complex dynamics between migrants and the locality. Chinese migrants are depicted as the long arm of the Chinese state and blamed for the impoverishment of the city and its loss of international relevance.

\section{La crise cachée : le district industriel de Prato et le déclin de l'industrie de la confection chinoise}

Ce texte examine la façon dont les migrants chinois et la ville/ID Prato concourent à la formation d'un lieu dans le cadre de la dynamique mondiale et nationale. II vise à documenter et à expliquer la dynamique en cours à Prato, en Italie, à une époque où I'industrie du vêtement, principalement gérée par les migrants chinois, est confrontée à des changements globaux et à des politiques locales restrictives qui menacent son existence même. Glick Schiller et Caglar (2011) suggèrent que les études sur les trajectoires d'insertion des migrants dans les villes appauvries dans le cadre de la restructuration mondiale peuvent contribuer à différentes analyses de la relation entre les migrants et leur lieu d'accueil. Cet article soutient que Prato est un cas exemplaire de ces nouvelles configurations issues du jeu des échelles - mondial, national et local dans les dynamiques complexes qu'entretiennent les migrants avec leur lieu d'installation. Les migrants chinois sont dépeints comme liés à l'État chinois et tenus responsables de l'appauvrissement de la ville et du recul de sa présence internationale.

\section{... La crisis escondida: el distrito industrial de Prato et la antes floreciente industria china del vestuario}

El presente estudio pretende analizar las formas como los migrantes chinos y la ciudad/ID de Prato constituyen juntos lo local en el marco de la dinámicas globales y nacionales. Propone documentar y explicar las dinámicas existentes en Prato, Italia, en un momento en que la industria de la confección, principalmente a cargo de los inmigrantes chinos, se enfrenta a los cambios globales y a las restrictivas políticas locales que ponen en peligro su propia existencia. Glick Schiller y Caglar (2011) sugieren que los estudios de las rutas migratorias de incorporación en las ciudades empobrecidas dentro de la reestructuración global pueden contribuir a un análisis diferente de la relación entre los migrantes y las ciudades. Este artículo sostiene que Prato es un caso ejemplar que da nuevas pistas sobre la interacción de las escalas global, nacional y local - en la compleja dinámica entre los migrantes y la localidad. Los inmigrantes chinos serian el brazo largo del Estado chino y serían responsables por el empobrecimiento de la ciudad y su pérdida de relevancia internacional. 